\title{
THE HUMAN RIGHTS ACT AND LOCAL GOVERNMENT: KEEPING THE COURTS AT BAY*
}

\section{Peter Leyland, Senior Lecturer, School of Law, Governance and International Relations, London Metropolitan University}

Local authorities as public bodies are not only subject to the HRA but are also responsible for the implementation of policy in many areas where human rights issues commonly arise, ranging from education, social services, housing, the environment and planning. Procedures of local authorities have been modified to take account of the provisions of the Act ${ }^{1}$ but commentators have remarked on the "paucity of empirical accounts of the impact of such rights on social attitudes and political processes. ${ }^{2}$ In conceiving this article, which draws attention to certain dangers in the new culture of human rights, I intended to commence the discussion by mentioning the positive impact of the Human Rights Act (HRA). Such a view was to be supported by mentioning ways in which the Act was effecting how local government now operated. The idea was to try to demonstrate that one important effect of the HRA has been to promote greater respect for Convention Rights. It was to be argued that the Act has encouraged an increased awareness of the potential impact of convention rights. One kind of evidence that might have been adduced in support of this view is exemplified by a consultation paper published by Camden Council on its draft interim licensing policy. This publication was in relation to the council's management of licensed activities, including public and private entertainment, night cafes, sex establishments and chairs on the public highway. ${ }^{3}$ The document points out that the European Convention is incorporated by the HRA and that it is unlawful for a local authority to act in a way which is incompatible with the convention. In respect to the policy in question, it is pointed out that article 6 requires a fair and public hearing within a reasonable time by an independent and impartial tribunal. In addition, it is pointed out that under article 8, everyone has the right to respect for his home and private life. This includes an entitlement to a good nights sleep. The case of Hatton v United Kingdom ${ }^{4}$ is cited in the consultation paper as authority for this view. ${ }^{5}$ While being

* This article originated from a paper given at a conference entitled: 'Governing After the Human Rights Act' held at London Metropolitan University in January 2003. I would like to thank Gordon Anthony and Professor Bill Bowring for their very insightful comments on an earlier draft.

1 See e.g. A Finlay 'The Human Rights Act: The Lord Chancellor's Department's Preparations for Implementation' [1999] EHRLR 512-519.

2 D Feldman (2002) 24 Legal Studies 651, reviewing T Campbell, K Ewing and A Tomkins (eds) Sceptical Essays on Human Rights (2001).

3 'Night In, Night Out: Draft Interim Licensing Policy', Consultation Paper, Camden Council, March 2002.

4 [2002] 34 EHRR 1.

5 In Hatton it was held that the policy allowing night flights into Heathrow was unlawful because it was in breach of art 8 of the ECHR. The majority came to this conclusion because they reasoned, applying a proportionality test, that the economic objective could not justify the degree of interference caused with the convention rights of the claimants. It is worth noting that the dissenting opinion of 
confident that further research would have unearthed many examples across a wide spectrum of policy areas, it also became clear that undertaking such a survey would have been a formidable undertaking in its own right. Nevertheless, I would like to suggest at the outset that the HRA is affecting the way local authorities and other public bodies are modifying their practices and that improved strategies of consultation might be cited as a benefit currently being enjoyed by citizens.

The discussion that follows concentrates on three questions concerning the Human Rights Act 1998, all of which have implications for local government. The first question discusses judicial policy towards the application of section 3 and section 4 of the Act. In particular, it considers the consequences of using either declarations of incompatibility, or purposive interpretation to undermine statutory schemes which confer powers on local government. The second question concerns an aspect of the public private law divide and relates to how far convention rights ought to be protected in situations where public bodies, such as local authorities, contract out the services which they are under a statutory obligation to provide. The third and final section focuses on how the influence of the HRA is leading to increased exposure of local authorities and other public bodies to liability in tort.

The central overall concern is to consider with reference to the questions outlined above the impact the Act is having on any constitutional balance that previously existed between Parliament, the executive and the courts. It is apparent that a clear policy dimension is emerging from recent judicial decisions. These are forming a new set of ground rules and differences in approach between senior judges will be discernible from close analysis of judicial positions. Moreover, it is important to recognise the massive constitutional importance of the reformulation of the relationship between the courts, Parliament and the executive. This is not intended as a theoretical discussion, but it needs to be made clear at the outset that the application of rights jurisprudence involves a genuine tension between different philosophical conceptions of the relationship between law and politics which are also represented in the judgments. ${ }^{6}$ For example at the extremes, it might be argued that the aim of liberal legalism, which represents one strand of this debate, is to secure 'the enclosure of politics within the straightjacket of the

Sir Brian Kerr rejects this reasoning and argues for a deferential approach. See G. Anthony 'Interacting Legal Orders and Inter-Court Disputes: The ECHR Beds into UK Public Law' in G Amato, G Braibant and E Venizelos (eds) The Constitutional Revision in Today's Europe (2002) p 577, 597.

6 For a recent example see the judgment of Laws LJ in Thoburn v Sunderland City Council [2002] 3 WLR 247 which provides a controversial discussion of sovereignty. But extra judicial contributions to the debate pre-date the HRA see e.g. J Laws 'Is the High Court the Guardian of Fundamental Constitutional Rights (1993) PL 63; Lord Woolf 'Droit Public-English Style' (1995) PL 57; S Sedley 'Human Rights: a Twenty-First Century Agenda' (1995) PL 386; Lord Irvine 'Judges and Decision-Makers: The Theory and Practice of Wednesbury Review' (1996) PL 59: and have continued since it reached the statute book: see e.g. Lord Hoffman 'Human Rights and the House of Lords' (1999) MLR 159; Lord Bingham 'Dicey Revisited' (2002) PL 39; Lord Steyn 'Human Rights: The Legacy of Mrs. Roosevelt' (2002) PL 473. 
law ${ }^{7}$ and such a court centred approach is underpinned by an assumption that answers to all political disputes can ultimately be found in law. On this view, the conferment of increased power on the judges as part of a new constitutional order is justified, not only by the failure of Parliament to protect rights, but by its more general demise as an effective counter-balance to 'elective dictatorship' in a situation where political opposition is weak and also ineffective. ${ }^{8}$ This is achieved by a new emphasis on human rights. ${ }^{9}$

On the other hand, human rights sceptics believing in a form of political constitutionalism might begin with an entirely different premise. Indeed, perhaps the central problem for them is that the theories of rights (e.g. ECHR) to which rights constitutionalists (as adherents of legal liberalism) tend to defer have not reconciled the very questions that lie at the heart of political debate. ${ }^{10}$ The point being that political constitutionalists recognise 'the inevitability of sustained disagreement over justice, policy and the content, meaning and priority of rights in circumstances of political pluralism'. ${ }^{11}$ From this perspective also, the reinforcement of liberal constitutionalism is likely to be an impediment to any progress with a social democratic agenda since it endorses a constitutional order that lacks any commitment to political and economic equality. ${ }^{12}$ The key issue comes down to determining who should ultimately decide these contested questions. Should this be achieved by means of a political process or by the courts? Those believing in a form of political constitution will prioritise the political over the legal and call for a theory of authority which demands a high degree of participation or equal participation in decisions over rights. Notwithstanding the problems of elective dictatorship, voter apathy etc. politics is regarded as the medium of conciliation. ${ }^{13}$ For political constitutionalists there should be a recognition of the importance of participation in decision making by ordinary people and this must be given priority over decision making by a supposedly expert minorities such as judges. Of course, these positions are included to broadly characterise opposing viewpoints. There are many stances which could be charted on a continuum between these polarities.

It is argued in this article that a form of political constitutionalism much closer to the latter view should prevail. This is because allowing routine

7 A Tomkins 'In Defence of the Political Constitution' (2002) 22 OJLS 157,169ff.

8 See A Lester 'Human Rights and the British Constitution' in J Jowell and D Oliver The Changing Constitution (2000) and A Lester 'Developing Constitutional Principles of Public Law (2001) PL 684.

9 However, any claim of neutrality here can be challenged. For if this path were to be followed, the Act might become the pretext for the courts to promote the narrow individualistic view of rights that is contained in the ECHR.

10 Perhaps the most vociferous and sustained scepticism has come from JAG Griffith see 'The Political Constitution' (1979) MLR 1 and more recently 'The Brave New World of Sir John Laws' (2000) MLR 156 and 'The Common Law and the Political Constitution' (2001) LQR 42.

11 N Walker 'Human Rights in a Postnational Order' in T Campbell et al (eds) n 2 above $\mathrm{p} 123 \mathrm{ff}$. This section of Walker's essay is a discussion of the ideas of $\mathrm{J}$ Waldron, Law and Disagreement (1999).

12 K Ewing 'The Unbalanced Constitution' in T Campbell et al (eds) n 2 above p 112 .

13 Tomkins $n 7$ above, 174. 
judicial challenges against local authorities and indeed other public bodies performing public duties will have adverse consequences for the community as a whole. While it might be desirable in some circumstances to provide citizens with remedies when their convention rights have been compromised, the courts should not be involved in the process of administration beyond establishing narrow questions of legality. In other words, the special powers of interpretation that have been given to the courts should be used with great restraint. The way forward in the public law domain is not to encourage the long drawn out process of litigation, or have judges decide matters of resource allocation, but rather to first consider the type of remedy that is appropriate and then to introduce a universal statutory system to deliver that form of relief on a universal basis. ${ }^{14}$ If systemic failings are identified, a declaration of incompatibility has the advantage of placing the ball firmly back in Parliament's court. It is for Parliament to introduce a remedy of general application. ${ }^{15}$

\section{(1) Applying the HRA: signs of judicial restraint?}

It is important to recognise that in the domain of public law the Human Rights Act has the potential to undermine statutory regimes under which policy is delivered. This could have far reaching implications for local government which often is made responsible for policy implementation by Parliament. From the time the HRA came into force there have been signs that the Act might disturb any balance between the courts and the executive. ${ }^{16}$ Although a court is not empowered to strike down primary legislation under section 4 , it can issue a declaration of incompatibility if it feels that legislation is incapable of an interpretation under section 3 that is compatible with the convention. ${ }^{17}$ This solution was intended to prevent parliamentary supremacy from being replaced by judicial supremacy. For example, the issue has arisen in respect to planning law. In $R$ (on the application of Alconbury Developments Ltd) v Secretary of State for the Environment, Transport and the Regions ${ }^{18}$ the Divisional Court found a structural incompatibility between article 6 and the system of planning appeals contained in sections 77-79 of the Town and Country Planning Act 1990. The matter was referred to the House of Lords for final resolution. Their Lordships overruled the decision of the Divisional Court as they did not accept that article 6(1) required a court to rehear the merits of decisions. Lord Clyde stated: 'We are concerned with an administrative process and an administrative decision. Planning is a matter for the formation and application of policy. The policy is not a matter for the courts but for the executive'. Nevertheless, the decision in the House of Lords recognised that

14 See e.g. The Housing Act 1996 and Homelessness Act 2002.

15 C Harlow "Public" and "Private" Law: Definition without Distinction' (1980) 43 MLR 241.

16 See R Carnwarth, 'The Reasonable Limits of Local Authority Powers' (1996) PL 244 who discusses the task of refining the negative restraints imposed on local authority powers and emphasises the importance of further developing framework principles to determine the relationship between central and local government.

17 There have been several declarations of incompatibility. See e.g. $R$ (on the application of International Transport Roth Gmbh) v Secretary of State for the Home Department [2002] 3 WLR 344.

18 [2001] UKHL 23; [2001] 2 WLR 1389. 
the convention rights of claimants had been effected and that such questions should be determined by an independent and impartial tribunal. It should be noted that, even if the House of Lords had supported the earlier decisions of the Divisional Court and the Court of Appeal, the system of planning appeals would have remained in operation until legislative changes were made with the approval of Parliament. ${ }^{19}$ This failure to issue a declaration of compatibility demonstrates a reluctance by the House of Lords to step in and effectively undermine the established statutory regime by adopting a different standard of proportionality review which lowered the threshold for intervention. It would appear from the views expressed by Lord Slynn that article 6 did not require judicial review to conduct a rehearing of the merits of planning policy, rather, he suggested, the focus of attention should be on the legality of decisions taken and on the procedures that have been followed. ${ }^{20}$ However, it has been argued that the House of Lords ducked the issue, which was simply whether the decision making under planning legislation in the current political climate was compatible with the Convention. By issuing a declaration of incompatibility their Lordships would not have been establishing an alternative form of decision making, but merely inviting Parliament to reconsider the question of whether current decision conflicted with convention rights. ${ }^{21}$ Finally, it should be stressed that the context, taking fully into account the statute and the nature of any interference with the convention right under question, will be crucial in determining whether a declaration of compatibility is issued by the court. ${ }^{22}$ To date, the indications are that the courts have been circumspect in exercising their powers under section 4 of the HRA.

The interpretative obligation to construe legislation compatibly with the Convention rights under section 3 of the HRA might be seen as an even more potent weapon in the hands of the courts and it is one that could open the door to merits review. ${ }^{23}$ Some commentators have argued that a refusal to

19 For another example of the involvement of the courts in the planning process under the Human Rights Act see $R$ (Friends Provident Life) v Secretary of State for the Environment, Transport and the Regions [2002] 1 WLR 1450. This concerned a challenge under s 77 of the Town and Country Planning Act 1990. The challenger arose after a local council had granted planning permission for a major shopping centre but the Secretary of State refused to set up an independent public inquiry. The court agreed that the claimant's rights had been affected by this failure to have an inquiry and that therefore art 6 of the Convention was engaged. However, the court held that there was no absolute rule that an inquiry had to be set up for determining matters that were essentially intra vires matters of planning judgment.

20 I Leigh, 'Taking Rights Proportionately: Judicial Review, the Human Rights Act and Strasbourg' (2002) PL 265, 272ff.

21 M Poustie 'The Rule of Law or the Rule of Lawyers? Alconbury, art 6(1) and the Role of the Courts in Administrative Decision Making' [2001] EHRLR 656, 672.

22 A case that might be contrasted with Alconbury is $H$. v Mental Health Review $N$ \& E London Region, The Times, April 4, 2001. In this instance a remedial order under s 10 followed the declaration of incompatibility concerning the reverse burden of proof at mental health tribunals. See J Wadham, 'The Human Rights Act: One Year On' [2001] EHRLR 620, 636ff.

23 Tower Hamlets LBC v Runa Begum [2002] 2 All ER 668. It was held by Laws LJ that although JR not appropriate for the resolution of factual disputes the judge had ample power to decide whether the decision could be properly made on the 
apply a possible section 3 interpretation cannot be justified, because to do so would be in breach constitutional principle by encroaching into the legislative sphere. It is suggested that such a non-interventionist approach undermines the intention of Parliament when it enacted the HRA. This appears to be a call for much more active judicial intervention in cases where convention rights are at stake. ${ }^{24}$ Others have pointed out that if new methods of purposive interpretation are adopted, which include conformity with convention rights, statutes could tend to be read down so that ECHR rights are given a higher status. Further, a morally purposive approach has the potential to be inherently expansive and creative. It will not be confined to rights but will apply to interpretation in general. ${ }^{25}$

There have been indications from the case law of emerging difficulties in the revised approach to statutory interpretation, this was apparent even before the HRA was fully in force For example, the contested issue in Macdonald v Ministry of Defence ${ }^{26}$ was the policy of the RAF in dismissing personnel on grounds of their homosexuality. It was argued before the Scottish Employment Appeal Tribunal that this practice was discriminatory and contrary to the Sex Discrimination Act 1975 (SDA). In determining the issue the Tribunal held that the word 'sex' in the Act should be read to mean 'sexual orientation'. However, the decision to construe sex in this way was overturned on appeal by the Court of Session. It was accepted by the appellate court that in deciding how to treat any individual those who apply the policy are concerned with sex as a matter of the gender of that individual. Both homosexual men and women were subject to dismissal and therefore were treated in the same way. On this view it followed that they were not discriminated against by virtue of gender. ${ }^{27}$

Lord Caplan explained how he viewed the court's role:

"I do not see the 1998 Act as requiring the insertion of omitted provisions so as to enhance the legislation under consideration. If there is a collision between that legislation and the Convention then one would look for a possible approach that may resolve the problem. However, that does not mean that omitted provisions should be added where no ambiguity exists and the scope of the Act is clearly not intended to deal with what is omitted."

An awareness of the dangers of a more interventionist stance is clearly discernible from the judgment in $\operatorname{Re} S$, Re W (Children) (Care Order: Implementation Care Plan). ${ }^{28}$ In this case the House of Lords was not prepared to follow the lead of the Court of Appeal in regard to the

available evidence. See F Klug and C O'Brien 'The First Two Years of the Human Rights Act' (2002) PL 649, 661.

24 R Clayton 'The Limits of What's "Possible": Statutory Construction under the Human Rights Act' [2002] EHRLR 559, 565.

25 T Campbell, 'Incorporation through Interpretation' in T Campbell et al (eds) n 2 above, $\mathrm{p} 84$.

26 [2001] 1 All ER 620; [2001] SLT 819.

27 See G Anthony, UK Public Law and European Law: The Dynamics of Legal Integration (2002), p 166.

28 [2002] 2 WLR 720. 
supervision of child care plans which had been justified on HRA grounds. The Court of Appeal had proposed a new procedure after a care order had been granted requiring a local authority to inform the child's parents of any departure from a care plan that might give rise to a risk that the human rights of the child or his parents might be infringed, so that an application might be made to the court for further directions. Lord Nichols stated that the court operated as the gateway into care and thereafter had no continuing role in relation to the care order which then became the responsibility of the authority. The reading by the Court of Appeal of the legislation under section 3 of the HRA went beyond interpretation and amounted to amendment of the Children Act 1989. Herring puts this in the clearest possible terms:

"At the end of the day, the real issue behind this case . . . is money. Local authorities have limited resources and cannot provide all of the services they would like for every child in their care. Sometimes financial difficulties mean that a local authority is not able to implement a care plan. To permit a court to compel local authority expenditure in respect of one child might cause great harm to other children in the local authority's care". ${ }^{29}$

Nevertheless, given the problems with the statutory scheme, this leaves open the question of how the children's rights are to be meaningfully protected under article 6 . It might be suggested that a declaration of incompatibility under section 4 would allow Parliament to amend the legislation so as to address the article 6 issue, but with the advantage that Parliament would be able to keep the general resource implications in mind when it considered amending the legislation. ${ }^{30}$

Adan $\mathrm{v}$ Newham $L B C^{31}$ is another recent case in which the courts resisted the call to intervene. In this instance it was argued that the local authority had been in breach of article 6 because the review officer handling homelessness claims was neither independent or impartial. ${ }^{32}$ Under section 204 of the Housing Act 1996 there was provision for an appeal to the county court on a point of law. However, it was argued that the disputed issues of fact should also be considered by the county court in order to render the procedure in conformity with article 6 . This approach was firmly rejected by the Court of Appeal as stepping beyond the mark. Brook LJ stated: 'It would involve a judicial sleight of hand to enlarge the jurisdiction of the county court beyond that given to it by Parliament. Parliament has decided that the local authority should be the final arbiter of the facts, not the courts, and the courts do not in my judgment, have the power to put these arrangement into reverse'.

29 J Herring 'The Human Rights of Children in Care' (2002) LQR 534, 538.

30 There have been a number of other case with resource implications. See e.g. Lee v Leeds City Council, The Times, January 292002 - an attempt to suggest that art 8 imposed an unqualified obligation on the authority to remedy problems caused by housing defects.

31 [2002] 1 All ER 931.

32 R Clayton $\mathrm{n} 24$ above, 564. This would suggest that purposive construction means that the Human Rights Act trumps other legislation in much the same way as the European Communities Act 1972. 
The issue for the House of Lords to determine in Begum $\mathrm{v}$ Tower Hamlets $L B C^{33}$ was whether the appellate procedure adopted by the council in the allocation of rented housing accommodation contravened the appellant's convention rights. The Court of Appeal's decision not to invalidate the statutory scheme was upheld in the House of Lords. In reviewing the Strasbourg jurisprudence ${ }^{34}$ on the requirements of article 6(1) in an administrative law context, Lord Hoffman observed that '. . . utilitarian considerations have their place when it comes to setting up ... schemes of regulation or social welfare' and that 'Parliament is entitled to take the view that it is not in the public interest that an excessive proportion of the funds available for a welfare scheme should be consumed in administration and legal dispute'. ${ }^{35}$ In his Lordships view the exercise of administrative functions do not necessarily require a mechanism for independent findings of fact or a full appeal, but any procedures adopted need to be lawful and fair.

From these decisions we can identify emerging guidelines indicating how far the court are able to depart from the scheme of the legislation in exercising their interpretative obligation. ${ }^{36}$ For the time being at least, the impact on administration is being contained by a cautious judicial approach which, once again, has attached considerable weight to the policy context. However, it has been argued that a concept of due deference needs to be developed which sets out principles to be applied by the courts in determining when intervention is appropriate in the contemporary constitutional context. ${ }^{37}$

\section{(2) Local Government and the Horizontal Impact of the HRA in the 'Contracting State'}

The next section of this article addresses a somewhat different problem, namely, the extent to which it is possible to protect convention rights given the trend towards governance which has increasingly led to the delivery of policy at a local level under contractual arrangements. In recent years it has been apparent that central government has 'asserted its pre-eminence . . . by stripping local government of many of its powers and much of its capacity for independent action . . . , ${ }^{38}$ Not only has there been a trend towards a concentration of power at the core of government but also the public dimension of the activities of local authorities have been progressively reduced by forms of privatisation so that many services, still nominally in the

33 [2003] UKHL 5; [2003] 2 WLR 388.

34 Bryan v United Kingdom (1995) 21 EHRR 342.

35 See Lord Hoffman at paras 43 and 44.

36 F Klug and C O'Brien n 23 above, 650ff.

37 See M Hunt 'Sovereignty's Blight: Why Contemporary Public Law Needs the Concept of "Due Deference"" in N Bamforth and P Leyland (eds) Public Law in a Multi-Layered Constitution (2003, forthcoming); J. Jowell, "Due Deference under the Human Rights Act", and Tim Owen, "Assessment of Fact, Due Deference and the Wider Impact of the Human Rights Act in Administrative Law" in J Jowell and Cooper (eds), JUSTICE/UCL Seminars (2002).

38 M Loughlin, 'Central Local Government Relations' in J Jowell and D Oliver (eds) $\mathrm{n} 8$ above, $\mathrm{p}$ 138. This stands in contrast to a tradition of municipal activism of Victorian councils. For a discussion of the emergence of the city in the nineteenth century see the introduction to A Briggs Victorian Cities (1968). 
hands of local government, are in fact actually carried out by private sector companies or other organisations ${ }^{39}$. The scene for this discussion must be set by reference to government policies which have removed the financial autonomy of councils ${ }^{40}$ and which have led more generally to a reduction of the powers of local government. This is to the extent that local government has ended up with performing what one commentator described little more than 'a residual market support function' ${ }^{41}$ It is true that, to a marginal extent, recent legislation has increased autonomy in some areas ${ }^{42}$ and the government has indicated that any conferment of greater freedom in the future will depend on authorities being able to demonstrate their capacity to modernise in line with the agenda it sets out. ${ }^{43}$

In addition, it is significant that Part I of the Local Government Act 2000 allows additional scope for authorities to develop participation with the community taking up the themes of partnership and 'joined up' government. ${ }^{44}$ Local government moves from merely being a service provider to having a role as community leader. This involves 'A multiorganisational, community-based process, initiated by the council, for creating a shared vision of community identified priorities leading to a programme of actions which demonstrate the commitment and support of the groups involved'. ${ }^{45}$ Sections 2 and 3 of the Local Government Act 2000 give local authorities powers to take any steps which they consider are likely to promote the well-being of their area or their inhabitants. For this purpose, under section 4, councils, together with other local bodies, must develop community strategies. These provisions are intended to give local authorities increased opportunities to improve the quality of life of their local communities. ${ }^{46}$ The approach here confirms that local authorities are to have a role in providing leadership and co-ordination on the policy front rather

39 Examples of services that have been put out to tender include: refuse disposal, street cleaning and road maintenance.

40 See M Loughlin Legality and Locality: The Role of Law in Central-Local Government Relations (1996). See e.g. The Local Government Finance Act 1992, ss $53-63$.

41 Loughlin, n 38 above, p 147.

42 For example, the best value regime under the Local Government Act 1999 and Part 1 of the Local Government Act 2000. Also, devolution has probably increased autonomy for local government in Scotland, Wales and Northern Ireland. However, T Hunt 'Freedom of the city' The Guardian, 29 July 2002 points out that local government has become a client state of Westminster with three quarters of its funds directly controlled from Whitehall. He maintains that 'to foster effective civic leadership, the government must allow councils the freedom to fail: to let them have access to the financial resources and political autonomy which have historically produced the most enterprising municipalities'.

43 See Modern Local Government: In Touch with the People (1998) Cm 4014 at para 2.17 .

44 See Modernising Government (1999) Cm 4310 and Modern Local Government: In Touch with the People (1998) Cm 4014.

45 V Jenkins, 'Learning from the Past: Achieving Sustainable Development in the Reform of Local Government' (2002) PL 130,138.

46 Although they were previously able to incur expenditure in the interests of their area under s 137 of the Local Government Act 1972 this was subject to many restrictions which are now relaxed by s 8 of the LGA 2000. 
than having responsibility for direct service provision ${ }^{47}$. If housing is taken as an example, the traditional method was for a local authority to rely on its own stock of council housing to satisfy social housing requirements (under statute) by providing rented accommodation for council tenants. In contrast, the role of the council under this new scheme: 'is to identify local needs and problems, and to respond flexibly to these by facilitating initiatives involving partnerships between a wide range of actors in the local, private and voluntary sectors' ${ }^{48}$ This suggests that councils will promote and oversee new schemes for low cost housing, but that the private and voluntary sector will be increasingly responsible for the implementation of such projects at every stage. ${ }^{49}$ It is apparent that the extent of contracting out by public bodies has been on the increase and that this trend is likely to be even more prevalent in the future. In sum, Local government as part of the contemporary administrative state, is to a substantial extent delivered by an assortment of hybrid bodies, voluntary organisations, and private companies. This has important implications when it comes to the application of the Human Rights Act because in providing a remedy when convention rights are at stake the reach of the HRA to these various bodies will have a bearing on its impact.

The Human Rights Act (HRA) has 'vertical' effect by requiring public bodies such as government, local government, the courts and the police in their dealings with the public to adhere to the convention. Section 6 is directed primarily at public authorities but it is clear that there are other ways in which convention rights apply 'horizontally' under the Act. ${ }^{50}$ The HRA gives no direct right to sue in the civil courts for an alleged breach of a convention right by another individual or private company, but the courts are a public body to which the Act applies. Therefore, if an action is taken to sue in the courts on a private law matter which involves interpreting a statute effecting convention rights, the courts are now required to interpret that statute, according to section 3 , in a way that is compatible with convention rights. The same obligation attaches to the common law which must be interpreted in a ECHR compatible manner. However, it should be noted that the Act makes clear that a remedy under section 8 can only be granted in

47 This is a trend which can also be linked to a broader principle of subsidiarity within the nation state. For example, in relation to proposals for a EU constitution Jack Straw has recognised the need to entrench and enforce the principle of subsidiarity on a community wide basis to ensure that decision making takes place at a local level. See speech by Jack Straw, Foreign Secretary to the Edinburgh Chamber of Commerce, August 27, 2002.

48 P Vincent-Jones 'Values and Purpose in Government: Central-local Relations in Regulatory Perspective' (2002) 29 JLS 27, 40.

49 For many years local authorities have worked in harness with voluntary sector organisations in this field. See e.g. Poplar v Donoghue [2001] 3 WLR 183 and Heather v Leonard Cheshire Foundation and HM Attorney-General [2001] EWHC Admin 429. For further analysis of these judgments see below and P Craig 'Contracting Out, The Human Rights Act and the Scope of Judicial Review' (2002) 118 LQR 551.

50 This was widely discussed before the HRA came into force. See $e . g$. M Hunt 'The "Horizontal Effect" of the Human Rights' (1998) PL 423, 435 and N Bamforth 'The Application of the Human Rights Act to Public Authorities and Public Bodies' (1999) 58 CLJ 159, $163 \mathrm{ff}$. 
respect of acts of public authorities. The HRA contains the important qualification that rights are generally asserted against public bodies by private individuals, and are not directly enforceable in respect of exclusively private bodies exercising private functions, or between private individuals. This means that the HRA places no direct obligations in regard to the conduct of private citizens, private companies and private organisations.

The courts are required to decide what constitutes public functions for these purposes, and, now that the Act is in force, it also has to be determined how far these provisions extend. This is complicated by the fact that, as we have just observed, the private sector frequently carry out high profile governmental services. These are often publicly funded (e.g., in the realm of health, education, housing, prisons and so on). While it is clear that ECHR rights are directly enforceable against public bodies in respect of all of their activities, it is far less clear whether rights are directly enforceable against hybrid bodies and private companies in respect of their public functions. ${ }^{51}$ The term "hybrid" has been used to describe arrangements which consist of a mixture of market and hierarchical ordering . . . Thus the concept precisely captures the notion of relationships ... which are partly based on contractual notions of exchange and partly on ... notions of hierarchical decision making. ${ }^{52}$ The position is that privatisation and contracting-out have now become the norm and thus we find that there are a new sets of contractual relationships. These may be between local authority and private company or service-provider and customer, but crucially, the public dimension is a statutory regime that establishes duties of service-provision, or powers of regulation. As Cane puts it: 'It is not that contract and statute operate side-by side in such a way that certain aspects of a relationship are governed by contract and others by statute. Rather the two elements are intertwined or blended with the result that the contract must be interpreted and applied in the light of relevant statutory provisions, and the statutory provisions must be interpreted and applied taking account of the contract' ${ }^{53}$

In determining the extent to which the HRA applies there are already some indications that the courts will give a narrow definition to what constitutes a public body and such an approach limits the scope of the Act. ${ }^{54}$ The issue in $R \vee$ Servite Houses and Wandsworth $L B C$, ex parte Goldsmith and Chatting ${ }^{55}$ was whether a housing association could close a residential home after a promise had been given to residents that they could remain in the home for the remainder of their lives. In other words did they have a substantive

51 See Human Rights Act section 6(3)(b) 'any person certain of whose function are functions of a public nature'.

52 C Scott, 'The Juridification of Relations in the UK Utilities Sectors' in Black, Muchlinski and Walker (eds), Commercial Regulation and Judicial Review (1998), p 59.

53 See P Cane 'Accountability and the Public/Private Distinction' in N Bamforth and P Leyland (eds) n 37 above.

54 In regard to the susceptibility to judicial review there has been an important debate over the definition of what constitutes a public as opposed to private body. Compare e.g. $R$ v Panel on Takeovers and Mergers, ex p Datafin [1987] 1 All ER 564 and $R$ v Disciplinary Committee of the Jockey Club, ex p Aga Khan [1993] 2 All ER 853

55 (2000) LGLR 997. 
legitimate expectation? However, any public law claim depended on first deciding whether a housing association which had terminated a contract constituted a public or a private body. Moses $\mathbf{J}$ rejected the idea that the local authority was acting as an agent of the local authority because there were no powers to delegate statutory obligations under the National Health Service and Community Care Act 1990. He then considered the source of the power. It was reasoned that, if the source of power of a body tended towards a statutory basis rather than being set on a contractual footing, this would be an important determining factor. This would be particularly so where a general regime of statutory control was discernible. However, in the instant case, he accepted that under section 26 of the National Assistance Act 1948 the local authority was able to enter into arrangements that divorced a service provider from its public law obligations. Accordingly, it was held that the courts were not in a position to impose public law standards upon a body the source of whose power were contractual. There was a lack of sufficient statutory penetration because the 1948 Act was not a statute that added public functions but one that allowed the discharge of obligations by private law arrangements. ${ }^{56}$

Paul Craig for one has been strongly critical of the reasoning above, which suggests that protection under the HRA will not apply when there is a contracting out situation. As a result, in these instances there will be no remedy available against the service provider. Craig observes that: 'It is a non-sequitur to assume that contracting out must inexorably mean that the service providers' obligations reside solely in private as opposed to public law. The imposition of public law obligations, and the HRA would not in any sense undermine the contracting out option provided for in legislation. It would simply mean that a private party entering into a contract with a public body for the provision of services would take these obligations into account when bidding for the work ... ${ }^{57}$ This seems a reasonable conclusion but the implications of extending liability more generally are discussed towards the end of this section.

Further analysis of what constitutes a public authority is provided in Poplar v Donoghue. ${ }^{8}$ The facts of this case were that the claimant contended that a possession order issued by a housing association was in breach of article 8 and article 6 of the ECHR. However, it first had to be determined whether housing associations, operating as registered social landlords after local housing authorities had transferred their stock of housing to them, were acting in a public or a private capacity. The Court of Appeal held that housing associations as a class are not standard public authorities but what can make an act by such a body, which would otherwise be private, public, is a feature, or a combination of features which impose a public character or stamp on the act. This might include providing accommodation for rent, charitable status, statutory authority etc. Lord Woolf also explained that, ' $[t]$ he more closely the acts that could be of a private nature are enmeshed in the activities of a public body, the more likely they are to be public'. The Court of Appeal came to the conclusion that while activities of housing

56 See Craig n 49 above, 561ff.
57 Ibid, 555 .

58 [2001] 3 WLR 183 
associations need not involve the performance of public functions, in this case, in providing accommodation for the defendant and then seeking possession, the role of Poplar was so closely assimilated to that of Tower Hamlets that it was performing public and not private functions. In this case no remedy was granted on the substantive issues. Lord Woolf recognised that distinguishing between interpretation and what might amount to judicial legislation was a difficult task that would be overcome by the practical experience of seeking to apply section 3 of the HRA. He went on to suggest that 'if it is necessary in order to obtain compliance to radically alter the effect of the legislation this will be an indication that more than interpretation is involved'. It was also recognised that this is an area in which '. . . the courts must treat the decisions of Parliament as to what is in the public interest with particular deference'.

The approach to justiciability in Heather v Leonard Cheshire Foundation and HM Attorney-General ${ }^{59}$ can be contrasted with that in Poplar v Donoghue. In this case a claimant sought to argue that a decision to close one of its homes by the Leonard Cheshire Foundation (LCF) was an infringement of article 8 of the Convention. To succeed the LCF must be fulfilling a public function to come under section 6 of the HRA. Residents are sent to the homes under statutory powers. Section 21(1) of the National Assistance Act 1948 states that local authorities must provide accommodation for claimants in need of care and attention. Lord Woolf stated that if the authority provides accommodation it is clearly performing a public function and that it is also a public function if it makes arrangements for the accommodation to be provided by the LCF. However, if a body which is a charity, like LCF provides accommodation to those to whom the authority owes a duty under section 21 in accordance with an arrangement under section 26, it does not follow that the charity is performing a public function. ${ }^{60}$ In other words, the mere fact that accommodation was funded by the local authority did not place the function in the public category. ${ }^{61} \mathrm{~A}$ contrast can also made here between Poplar which was a statutory housing association formed to take over the council's housing stock, and the Leonard Cheshire foundation which always has been a non-statutory charitable organisation specialising in the provision of residential care.

Despite his analysis and findings on the issue before him, Moses $\mathbf{J}$ remarked in the Servite Homes case above:

"I cannot conclude this matter without expressing my sympathy for the applicants. The case represents more than tension between public law and private law rights, but a collision. If I am right in my reasoning, it demonstrates an inadequacy of response to the plight of applicants now that

59 [2001] EWHC Admin 429.

${ }^{60}$ Ibid. Craig, n 49 above, points out at 556 that this conclusion is counter intuitive. It is difficult to see why the nature of a function should alter if is contracted out rather than performed in house.

61 It has been argued that the Leonard Cheshire case is an example of where a hybrid authority exercises a public function in relation to some persons but not others. See also J Johnston 'The Meaning of "Public Authority" under the Human Rights Act' [2001] JR 250, p 253. 
Parliament has permitted public law obligations to be discharged by entering into private law arrangements". ${ }^{62}$

At first encounter, in circumstances where a statutory function is being met by a contracting arrangement, it is difficult to see why protection under the HRA should vary with the method of service delivery. A test according to a list of criteria, such as those set out in Poplar v Donoghue, is bound to end up in drawing lines in the sand somewhere which inevitably results in preventing certain claimants from taking action. There are obvious reasons for introducing HRA protection in regard to the performance of public functions with statutory underpinning standing behind the provision of services. This is particularly the case in such areas as care for the elderly or the provision of rented accommodation to the most needy applicants, as in the cases discussed above. However, as was noted above, Lord Woolf in Poplar v Donoghue was in no doubt that the courts must treat the decisions of Parliament under the housing legislation as to what is in the public interest with particular deference. He pointed out that a procedure which ensured possession could be obtained expeditiously had been provided by Parliament. Poplar should follow this procedure when considering the rights of tenants under article 8. Also, it was relevant that tenants had remedies besides those provided under section 21(4) of the Housing Act 1988. ${ }^{63}$ Equally, there is a recognition that if the court had found in favour of the tenant this would have resulted in queue jumping to the detriment of others on the housing list who were perhaps in circumstances of greater need. However, we have seen it convincingly argued by Craig that there is nothing in the nature of contracting out which, in principle, suggests that the HRA should not apply to private or voluntary bodies under a contracting out agreement. ${ }^{64}$

If we pause to consider the possible implications of a more interventionist approach, are there good reasons for the judicial caution that has so far been exercised? Assuming that the courts decided to adopt a broad functions test, which subjected the private sector or voluntary sector organisations to claims under the Human Rights Act: would this have a detrimental impact on the way the system operated? I believe that this might undermine the implementation of schemes administered by local authorities, such as those in the cases discussed above. It could lead to the possibility that private and voluntary organisations entering into contracts with local government (and other public bodies) would have to face the possibility of a new category of claims. To date in cases of this type, the courts have recognised in certain circumstances that residents might enjoy a legitimate expectation. This could be that a home will remain open for their lifetime. In particular, this will be if there has been an express promise ${ }^{65}$ but what would be the outcome

$62 R \mathrm{v}$ Servite Houses and Wandsworth LBC, ex parte Goldsmith and Chatting (2000) LGLR 997, 1025.

63 As per Lord Woolf in Poplar v Donoghue [2001] 3 WLR 183

64 See Craig, n 49 above, $564 \mathrm{ff}$.

65 In $R$ v North and East Devon Health Authority, ex $p$ Coughlin [2000] 3 All ER 850 it was held that because of an express promise not to close a home a substantive legitimate expectation arose which could only be departed from if there was a sufficient overriding interest. It was also acknowledged that the closure of the home would be an interference with the rights of residents under art 8 . 
if it were held that a decision to close a home constituted a breach of respect for private and family life and that this was not justified under the exceptions referred to under article 8(2)? This would have a radical impact, as it could result in a requirement to keep open homes for the elderly that were proving to be a drain on resources. It might also be argued that a remedy for breach of article 8 should be awarded. This might be in the form of grants of compensation for the disruption caused through the closure of homes. ${ }^{66}$ It would appear to follow that if the financial consequences of such claims turned out to be substantial, the private and voluntary sector organisations would indemnify themselves by taking out insurance, or do so directly by other charges. The upshot would be that the cost would be passed on as part of the bidding process, and ultimately it would have to be met by the public authority charged with carrying out the statutory duty. The increased cost of the satisfaction of individual claims would impact on the unit cost of providing the service, and the reduction in the resources available to the authority would then have an effect on the extent of the service provision and standard of the service provided. It should be remembered that under the ECHR civil and political rights are made justiciable while social and economic rights are not. In preference to a case by case approach, it is possible to envisage rights based claims leading to more limited procedural remedies open to individuals caught up in the contracting out of services. ${ }^{67}$ Indeed, it might be argued that in order to provide effective redress, as is necessary and desirable to satisfy article 13, a new form of remedy is called for. It is proposed that this might be cast in terms of a new statutory right for certain classes of citizens in receipt of such benefits. They would have a right to adequate and meaningful consultation and perhaps also to limited compensation. At the same time the introduction of the remedy would also prevent routine questions of resource allocation from being determined by judicial intervention.

\section{(3) Human Rights and Tort Liability of Local Authorities}

Extending the tort liability of public authorities will have a very significant affect on local government and this is another area where there have been indications of the influence of human rights considerations on domestic law. ${ }^{68}$ For example, it is now unlawful under section 6 for a public authority to act in a way which is incompatible with a Convention right and a person who claims that a public authority has acted, or proposes to act, in a way which is made unlawful under section 6 may bring proceedings against the authority under section 8 . It has been suggested that this will mean in practice that the common law will have to evolve in a manner which is compatible with the Convention. ${ }^{69}$ In regard to this discussion article 6 of

66 Under HRA 1998 s 8 a court is empowered to grant a remedy but damages can only be awarded by a court which has a power to award damages, or to order compensation in civil proceedings.

67 Ewing n 12 above, p 111 acknowledges with reference to $R \mathrm{v}$ North and East Devon Health Authority, ex p Coughlin [2000] 3 All ER 850 that the ECHR and HRA have the capacity to enhance social rights in limited respects by regulating the allocation of services.

68 C Gearty, 'Tort Law and the Human Rights Act' in T Campbell et al (eds) n 2 above, p 243.

69 Ibid at 255 
the Convention can be seen to have particular importance. It requires that that everyone should be entitled to a fair and public hearing within a reasonable time by an independent and impartial tribunal established by law. It should also be remembered that the jurisprudence from Strasbourg (including $Z \vee U K$ ) has to be taken into account under section 2(1) but is not binding on the UK courts. However, the controversial Osman decision in Strasbourg found that the strike out provisions were in breach of article 6(1). These required that it must be fair, just and reasonable to impose a duty of care. Added to this, following the introduction of the HRA, it would appear that there is a presumptive right to pursue a public authority in damages for breach of statutory duty.

Turning to domestic law, the judgment of Lord Browne-Wilkinson in $X \mathrm{v}$ Bedfordshire ${ }^{70}$ set limits on the exposure of local authorities (and other public bodies) for damages in the exercise of their statutory duties and powers (as opposed to free standing causes of action). It had established that on a general basis it was not just and reasonable for them to be subject to a duty of care enforceable by damages for the exercise of statutory duties and powers. This was not however an unqualified immunity in circumstances where they were exercising statutory powers but was made subject to certain provisos. These were set out in $X \mathrm{v}$ Bedfordshire and further explained by Lord Hoffman in Stovin v Wise ${ }^{71}$ : 'The minimum preconditions for basing a duty of care upon the existence of a statutory power, if it can be done at all, are first, that it would in the circumstances have been irrational not to have exercised the power, so that there was in effect a public law duty to act, and secondly, that there are exceptional grounds for holding that the policy of the statute required compensation to be paid to persons who suffer the loss because the power was not exercised'. That is to say that there was a public law Wednesbury threshold of unreasonableness that had to be surmounted in assessing the conduct of the decision maker before liability can arise. Before proceeding to consider the subsequent case law, it is important to recognise that the Human Rights Act 1998 has seen the introduction of a proportionality test which applies where convention issues are at stake. It is clear from that proportionality operates on a different basis to Wednesbury. As Lord Steyn explained in $R \mathrm{v}$ Secretary of State for the Home Department, ex parte Daly ${ }^{72}$ a court now has:

"to assess the balance which the decision maker has struck, not merely whether it is within range of reasonable decisions. Secondly, the proportionality test may go further than traditional grounds of review in as much as it may require attention to be directed to the relative weight accorded to interests and considerations. Thirdly... the intensity of review ... is guaranteed by the twin requirements that the limitation of the right was necessary in a democratic society, in the sense of meeting pressing social need, and the question whether the interference was really proportionate to the legitimate aim being pursued".

70 [1995] 2 AC 633.

71 [1996] AC 923 at 953.

72 [2001] 2 WLR 1622 at 1635. 
It has been suggested that this makes judicial review more intensive and brings public law closer to the test applied in private law. It is now apparent that in any claim with a human rights dimension to it: 'the court is obliged to exercise an independent judgment as to the propriety of the action when weighed against the human rights in question'. And, if this is so, there can be no automatic restriction on public law liability. ${ }^{73}$

A policy/operations dichotomy is another factor that has been relevant in the public sphere. In general decisions regarded as matters of policy have been regarded as non-justiciable while negligent operational decisions have tended to be more susceptible to challenge. ${ }^{74}$ There has been a recent crop of decisions which indicate that public services have been more widely exposed to claims of compensation for negligent conduct. For example, there have been cases involving fire service and police forces with an operational dimension to them. The first signs of this change in approach were apparent in Capital and Counties and Digital Equipment v Hampshire $C^{75}$ where it was found that a fire authority could be held accountable in regard to property destroyed because of negligent fire fighting. After a blaze had broken out in commercial premises the station officer ordered the sprinkler system to be turned off. As a direct result control over the fire was lost and the building destroyed. Under the third limb of the Caparo test it was held to be 'fair, just and reasonable' to recognise a duty of care in these circumstances. $^{76}$

In Barrett $\mathrm{v}$ Enfield $B C^{77}$ the House of Lords acted to qualify the immunity recognised in $X \mathrm{v}$ Bedfordshire. They did so before the HRA came into force and without expressly invoking Osman (It is worth noting that the Osman case is not relied upon by the Law Lords as the basis for their decision.). Their Lordships unanimously decided to overturn a decision by the Court of Appeal striking out a negligence claim against a local authority. In view of the ever increasing media profile of cases involving the abuse of children in recent years, it is worth noting that the facts were that $\mathrm{P}$ suffered physical abuse from his natural parents and was taken into local authority care as a very small child. After a lapse of time he was placed by the local authority with a succession of different foster parents. However, these placements proved problematic and he was moved to a number of different children's homes. By the time he was released from care at the age of 17 a pattern of very disturbed behaviour had manifested itself. The basis of the claim was that his behavioural problems originating from an early age could be attributed to negligent treatment at the hands of the council. It was

73 C Newdick 'Damages for Public Authority Negligence - Public Interests and the Human Rights Act' (2002) 10 Tort Law Review 127, 140.

74 As Lord Slynn explained in Barrett v Enfield BC [1999] 3 WLR 79: 'The greater the element of policy involved, the wider the area of discretion accorded, the more likely it is that the matter is not justiciable so that no action in negligence can be brought'.

75 [1997] 1 QB 1004.

76 A change in direction is also apparent in regard to cases involving the police. See Swinney v Chief Constable of the Northumbria Police [1997] QB 464; Darker v Chief Constable West Midlands [2000] WLR 747.

77 [1999] 3 WLR 79. 
contended that the authority had been in breach of a common law duty of care owed to him.

The Court of Appeal had upheld an earlier decision to strike out the case. This was partly on the basis that the action rested on showing that the council had negligently exercised its statutory discretion. On this point the Court concluded that, since it was unlikely that the Wednesbury threshold of unreasonableness could be demonstrated in the exercise of its discretion, the action was likely to fail. It was further held by Lord Woolf MR (as he then was) in the Court of Appeal that, although the first two requirements in Caparo Industries v Dickman of foreseeability and proximity were satisfied, the third requirement was not. Therefore, it would not be just and reasonable in the present case to impose a duty of care on a local authority for the careless exercise of a statutory discretion. However, their Lordships came to a different conclusion on the crucial issue of striking out. This was on the basis that no duty of care was owed.

It should be stressed again that there was no direct reference to the Human Rights Act and the Act was not in force when the House of Lords decided the case. However, it was obvious that the court was aware of developments in Strasbourg. In particular, Lord Browne-Wilkinson provided strongly critical appraisal of Osman (which has been vindicated by the decision in $Z \mathrm{v} U K$ ). His judgment recognised the potential impact of the Human Rights Act 1998 in preventing such cases from being struck out. However, Lord BrowneWilkinson pointed out that a guarantee of rights under article 6(1) applied only in circumstances where an individual had a pre-existing right to a hearing under domestic law which was then denied. The point being that the striking out procedure, which had been adopted did not restrict access to a court, but was made after deliberation on the question of a duty of care. As Gearty points out: "The meta-confusion lying at the heart of the Osman/Z line of cases from a UK point of view relates to the question of what constitutes 'an immunity". ${ }^{78}$ There was no liability to be immune from, because the third limb of the Caparo test was missing. Indeed, the decision by the EctHR in $Z$ recognises that in relation to article 6 'the inability of the applicants to sue the local authority flowed not from an immunity but from the applicable principles governing the substantive right of action in domestic law'. ${ }^{79}$ The position following $Z$ appears to be that a court must determine whether article 6(1) applies to any given situation and if it does so, the court must go on to decide whether there has been a breach in terms of the procedural safeguards that are required under article 6 . Lord BrowneWilkinson recognised that this introduced the prospect of an exclusionary rule having to be decided afresh in each individual case. Osman also raised other awkward questions. For example, any revised approach would need to take account of circumstances where a view has been taken that the imposition of liability would not be fair and reasonable in the circumstances and Lord Browne-Wilkinson reiterated the difficulty in identifying a clear boundary between decisions falling under the head of policy and discretion, and those matters that are considered as falling under the ambit of operations.

78 C Gearty, 'Osman Unravels' (2002) MLR 87, 90.

79 [2001] 2 FLR 612; Application 29392/95. 10 May 2001 para 100. 
In his judgment, Lord Slynn makes a crucial distinction between the facts in $X \mathrm{v}$ Bedfordshire and the Barrett case. The former was non-justiciable because the contested decisions concerned the exercise of a statutory discretion. In $X \mathrm{v}$ Bedfordshire itself the central issue was deciding whether a child should be taken into care. While the latter case concerned acts done after a child had been taken into care. His Lordship reasoned that although the decision to take the child into care might not be found open to question, it did not follow that the child's subsequent treatment at the hands of the authority was not actionable. Any such treatment concerned the ways in which the powers of the authority were exercised at an operational level.

The position adopted by the House of Lords in Barrett is that a claim should only be struck out if operational carelessness could not have caused the damage or injury. Lord Slynn recognised that the allegations concerned the way in which the powers of the local authority were exercised and he suggested that there is jurisdiction to consider, first, whether there is a duty of care in respect of these acts. Second, in considering whether this duty has been broken, once it is shown that there is an arguable case, this becomes a question to be determined by the court on the facts. Thus the focus of attention has shifted to the breach stage. Any liability will ultimately depend on the capacity of the plaintiff/claimant to establish a causal link between negligent operational acts and any resulting psychological injuries. If the negligence was not caused by the operational acts of the authority, but flowed from policy decisions there will be no liability. But their Lordships held that the mere fact that there was a statutory discretion did not rule out the possibility of liability. At an operational level the court regarded social workers as skilled professionals who were in an analogous position in regard to owing a duty of care to other comparable groups such as health care professionals and teachers. ${ }^{80}$

The House of Lords has since decided that a local authority can be vicariously liable in respect to the provision of education and educational services. In Phelps v Hillingdon $L B C^{81}$ three of the claimants were suffering from severe educational difficulties and were referred by the local authority to expert educational psychologist who failed to identify dyslexia. It was argued that in each case severe problems flowed from the misdiagnosis. These consequences ranged from lack of educational progress, to social deprivation and psychiatric injury. G, the final claimant, was a boy with Duchenne muscular dystrophy who had been removed from a mainstream school and transferred to a school with facilities for special disabilities, but not provided with computer technology and suitable training to cope educationally. Likewise this claimant suffered from lack of educational progress, social deprivation and psychiatric injury in the form clinical depression. $^{82}$

It was held that a person exercising a particular skill or profession might owe a duty of care in its performance and it was stressed that those engaged in education should possess and observe the highest standards. 'Since it was

80 P Craig and D Fairgrieve, "Barrett, Negligence and Discretionary Powers" (1999) $P L 626,633$.

81 [2000] 3 WLR 776 .

82 M Harris, 'Education and Local Authorities' (2001) LQR 25. 
clear that that the child's parents and teachers would act on the advice a duty of care arose. The professional should exercise reasonable skill and care when assessing the child and then when advising the educational authority'. Lord Nichols stated that this '. . . seems to me to be, on its face, an example par excellence of a situation where the law will regard the professional owing a duty of care to a third party as well as his own employer'. To put it simply, 'the adverse consequence of the plaintiff's dyslexia could have been mitigated by early diagnosis and appropriate treatment or educational provision'. Accordingly, it was also held that the authority could be vicariously liable for the negligence of its educational psychologist for the failure to discharge a statutory duty arising under the Education Acts 1944 and 1981 which was to make a correct diagnosis dyslexia. Although a right to pursue a claim is recognised by this decision, it should be noted that the litigant is still faced (as recognised in Barrett above) with the task of establishing a causal link between the erroneous diagnosis (of dyslexia), the subsequent educational problems that have been experienced and any psychiatric injury that it is claimed has resulted from this. The question for the court will be whether any foreseeable harm has been inflicted on the plaintiff. The upshot is that teachers and educational psychologists acting in an advisory capacity are placed under an equivalent duty of care to doctors, lawyers and other persons with an equivalent type of special skill, and that a local authority employing them will be vicariously liable in respect to their negligent acts and omissions.

As has been pointed out, Phelps has gone significantly further than Barrett in extending liability. This is first because it was held that the claim was fully justified and liability was upheld on the basis of facts established in court. Secondly, it is because the 'practical' difficulties in establishing a duty of care in education cases was not allowed to stand in the way of making a deserving claim. ${ }^{83}$ The argument that this would lead to defensive practices was not accepted by their Lordships. In fact, the court took on board the alternative view, namely, that recognising a duty of care would drive up standards and act as a deterrent for sloppy conduct. The danger that this would open the floodgates to a torrent of litigation was also rejected. The Bolam test ${ }^{84}$ would serve as a deterrent for unmeritorious claims because this requires the claimant to show that the professional concerned did not exercise the skills of a competent professional. This requires the claimant to convince the court that there had been a failure to act in accordance with the accepted views of a substantial reputable body of opinion. In other words the standard set by the professions are taken into account by the courts and this will constitute an obstacle for ill founded claims. ${ }^{85}$ Lord Nichols stated in Phelps $\mathrm{v}$ Hillingdon $L B C{ }^{86}$ that teachers must owe a duty of care to all their pupils. The exclusionary rule has been relaxed but the question of direct liability for teachers was not resolved, nor have the limits of liability been clearly defined.

83 D Fairgrieve, 'Pushing back the Boundaries of Public Authority Liability: Tort Law Enters the Classroom' (2002) PL 288, 295.

84 Bolam v Friern Hospital Management Committee [1957] 1 WLR 582.

85 Fairgrieve $\mathrm{n} 83$ above, 302.

86 [2000] 3 WLR 776. 
The influence of EU law is another factor to be taken into account here. It has been pointed out ${ }^{87}$ that by not awarding damages for breaches of statutory duty in cases such as $X \mathrm{v}$ Bedfordshire there was a sense in which the House of Lords appeared to be travelling in the opposite direction to EU jurisprudence. It will be remembered that national courts under the doctrine of state liability are required to award damages to an individual whose EU law rights have been breached. Since the principle was established by the ECJ in Francovich and Bonifaci $\mathrm{v}$ Italy, ${ }^{88}$ recovery of damages has been allowed against national governments for a sufficiently serious breach of community law which takes place irrespective of fault. ${ }^{89}$ It has been argued that a process of harmonisation for UK domestic law is called for in order to correct the discrepancy ${ }^{90}$ of approach between EU and domestic law. In essence, the proposal is that a comparable common law liability for unlawful administrative acts could be developed, with the important requirement of sufficient seriousness providing some flexibility for the courts in reconciling competing interests. ${ }^{91}$

\section{CONCLUSION}

We must recognise that the HRA is having a profound impact on the constitutional balance between Parliament, the executive and the courts. At the outset we noted that some commentators broadly welcome the more prominent judicial role under the HRA and view this as a response to executive dominance and many perceived shortcoming in parliamentary control. However, although there may be some gains in protecting certain rights by judicial intervention, it is argued here that '. . . law is not and cannot be a substitute for politics'. ${ }^{92}$ This assertion has a contemporary resonance and it has provided the context for our discussion. As Professor Griffith recognised 'the danger of arguing from rights is that the real issues can be evaded. What are truly questions of politics and economics are presented as questions of law'. ${ }^{93}$ In relation to the preceding discussion, the Barrett and Phelps decisions are related to the new rights based culture. It is becoming clear that this relaxation in immunity is part of wider trend allowing litigation against public authorities. ${ }^{94}$ This has been particularly evident in the National Health Service. For example, it is reported that as a

87 See Anthony n 27 above, p 143; W Wade and C Forsyth Administrative Law (2000), p 763.

88 [1991] ECR 1-5357.

89 See $R$ v Secretary of State for Transport, ex p Factortame (No 5) [1999] 3 WLR 1062 .

90 R Carnwath 'Welfare services: liabilities in tort after the Human Rights Act' (2001) PL 210, 217ff.

91 See Anthony n 27 above, p 142ff for an expanded discussion of the wider debate over the integration of European Union law. For two opposing views on this question see: P Craig, 'Once More Unto the Breach: The Community, The State amd Damages Liability' (1997) 113 LQR 67 and J Allison 'Transplantation and Cross-fertilisation' in J Beatson and $\mathrm{T}$ Tridimas (eds), New Directions in European Public Law (1998), p 169.

92 JAG Griffith 'The Political Constitution' (1979) MLR 1, 16.

93 Ibid, 17.

94 Relaxing the striking out rule so that more cases to go to trial appears to run contrary to the spirit of the reforms in case management introduced under the Civil Procedure Rules of 1999. 
result of litigation the amount of compensation paid by insurance companies and public authorities amounts to one per cent of GDP, and that the figure is growing by 15 per cent a year. ${ }^{95}$ It has been pointed out that allowing claims to soar in the health service gives rise to problems which inevitably have resource implications. ${ }^{96}$ The crucial factor to keep mind is that health authorities are not in the same situation as private hospitals. They are under an obligation to provide their services free at the point of delivery for those that need them, and they must achieve this within limited budgets. This has implications for doctors working overlong hours, as it does for patients treated by these doctors. Exposure to general liability is a fundamentally inefficient way of delivering compensation. Indeed, the cost of claims has become so great $^{97}$ that the government is currently considering how to introduce a statutory scheme which seeks to achieve 'a more responsive and patient focused approach to both complaints and clinical negligence claims handling, which provides remedies more closely tailored to individual patients' needs - including practical, non-financial and financial remedies which address concerns directly and quickly'. ${ }^{98}$ Equally, the anticipated growth in litigation across the public sector will have serious consequences for local government in its capacity as the provider of education, social services and housing. For example, it has been argued that the new approach to striking out post Barrett will encourage claims. This is because defendant authorities cannot recover costs against claimants eligible for legal aid. As well as more cases going before a court, the likely result is that local authorities and other public bodies will increasingly be inclined to settle rather than run the risk of trial and the prospect of defeat. ${ }^{99}$

It has been argued by some commentators that: '. . . the Human Rights Act has already transferred an extensive legislative power to the judges. But Parliament has not explicitly given away its general policy or resource allocation powers, and it would be quite wrong for the courts to use the Human Rights Act in order to seize the initiative in such areas. ${ }^{100}$ In regard to the assessment of the initial case law arising directly from the Human Rights Act, we have observed that there has been, on the whole, remarkable judicial restraint, with an acute awareness of the dangers of encroaching on the most sensitive political territory. ${ }^{101}$ In addition, as was also noted above, a response to rulings by the domestic courts and the ECHR opening up

95 R Verkaik "Lawyers Earning $£ 3$ billion yearly from UK injury culture", The Independent, 17/12/02. The Cost of Compensation Culture; J Rosenberg 'The Price of Suing for every mishap is $£ 10$ billion’ Daily Telegraph 17/12/02.

96 C Newdick $n 73$ above, 132.

97 Clinical negligence: what are the issues and options for reform? National Audit Office report 2002. This put the projected figures for claims at $£ 3.9$ billion.

98 Handling Clinical Negligence Claims in England: Report by the Comptroller and Auditor General HC403, Session 2000-2001, 3 May 2001. New schemes might involve establishing tribunals or introducing a commission to mediate, arbitrate and determine claims.

99 See Craig and Fairgrieve, n 80 above, 638. The extent to which this is happening is obviously difficult to precisely quantify as many claims are not reaching court.

100 Gearty n 68 above, p 256.

101 See e.g. $R$ (on the application of Alconbury Developments Ltd) v Secretary of State for the Environment, Transport and the Regions [2001] UKHL 23; [2001] 2 WLR 1389 above. 
liability in further policy areas, is likely to be legislation designed to provide a remedy and therefore prevent potential challenges under article $13 .{ }^{102}$ In fact, there is a strong case for introducing statutory schemes for no-fault compensation in the public sphere which, in all but the most serious cases, would replace the costly and inefficient option of litigation. ${ }^{103}$ The wider availability of statutory remedies would have the effect of outflanking a more general move towards litigation under the HRA, but at the same time, it satisfies the requirement of providing a remedy under the Convention.

Moreover, the suggestion (which was made in Phelps above) that the threat of legal action will act as the catalyst for the improvement of standards in any public service environment, whether it be social services, housing, education or the health service, is very difficult to sustain, given the complexity of the systems of management and the number of players that are often involved in the delivery of these services. Rather, there is considerable evidence to suggest that the prospect of litigation is counter productive and merely results in a safety first approach by public sector organisations of defensive and self-justifying conduct. However, it must be acknowledged that there are members of the public who feel intense anger and frustration at the lack of an adequate response from public bodies when things go seriously wrong. Accordingly, it is argued that there also needs to be radical reform of internal disciplinary procedures and accountability systems of public bodies to make professionals and other players working in these fields more accountable for their actions in the context of their employment and also to increase operational transparency. ${ }^{104}$

102 Also, local authorities may well modify their modes of operation to comply with the decision in $Z \mathrm{v} U K$ (and others like it) by adopting a procedure that provides an intra vires remedy.

103 See C Harlow, Understanding Tort Law (1994), p 183.

104 See the inquiry presided over by Lord Laming into the death of Victoria Climbié Social Services Minister Jacqui Smith stated 14/10/02: "The government is committed to improving safeguards for children, and has introduced new legislation, new guidance, new structures and new policy initiatives to make children safer and to ensure that there is a proper focus on children at the very heart of government." Revised codes for professional bodies are another path to obtaining improved standards. 